\title{
Predictions of changes of glacier mass balance in the Nepal Himalaya and Tibetan Plateau: a case study of air temperature increase for three glaciers
}

\author{
Yutaka Ageta And Tsutomu Kadota \\ Water Research Institute, Nagoya University, Nagoya 464, Japan
}

\begin{abstract}
Annual mass exchange differs between maritime and continental glaciers. A common characteristic of these glaciers in Asian high-mountain areas is that most of the annual accumulation occurs in summer. Since variations in mass balance of a summer-accumulation type of glacier are quite sensitive to variations in summer air temperature, shrinkages of such glaciers due to climate warming are predicted by the use of simplified experimental relations between air temperature and mass balance, disregarding variation of other climatic variables such as cloudiness and precipitation. The results predict that both small and large maritime glaciers are more sensitive to warming than a continental ice cap. A small glacier would disappear in a few decades if the air temperature persisted a few degrees above that of an equilibrium state of mass balance.
\end{abstract}

\section{INTRODUGTION}

In the Himalayas and Tibetan Plateau, maritime and continental glaciers are located in humid and dry climates respectively, and with different values of annual mass exchange. A common characteristic of the mass balance of these glaciers is that most of the annual accumulation occurs in summer; such glaciers were called "the summeraccumulation type" by Ageta and Higuchi (1984).

If summer air temperature rises in areas where air temperature is in the critical range to change snow to rain, the ratio of snow to total precipitation decreases and the accumulation on glaciers, such as the maritime glaciers, decreases even with no change in total precipitation. The decrease of summer snowfall accelerates ablation due to lowering of the albedo at the glacier surface. Hence, glacier fluctuations of the summeraccumulation type are quite sensitive to variations in summer temperature. However, such sensitivity is different for large glaciers and small glaciers, since large glaciers have wide accumulation areas extending to high cold altitudes and thick supraglacial debris in the ablation areas.

If air temperature rises in the future, variations of the summer-accumulation type glaciers would affect the water cycle and water resources. Predictions of shrinkages of such glaciers are attempted in this paper by the use of simplified experimental relations between air temperature and glacier mass balance. The empirical models are based on continuous observations within one or two years in the Himalayas and Tibetan Plateau. Three glaciers of different types were selected for the study: a small glacier in east Nepal (Glacier AX010: $0.57 \mathrm{~km}^{2}$, of sub-maritime type), a large glacier in east

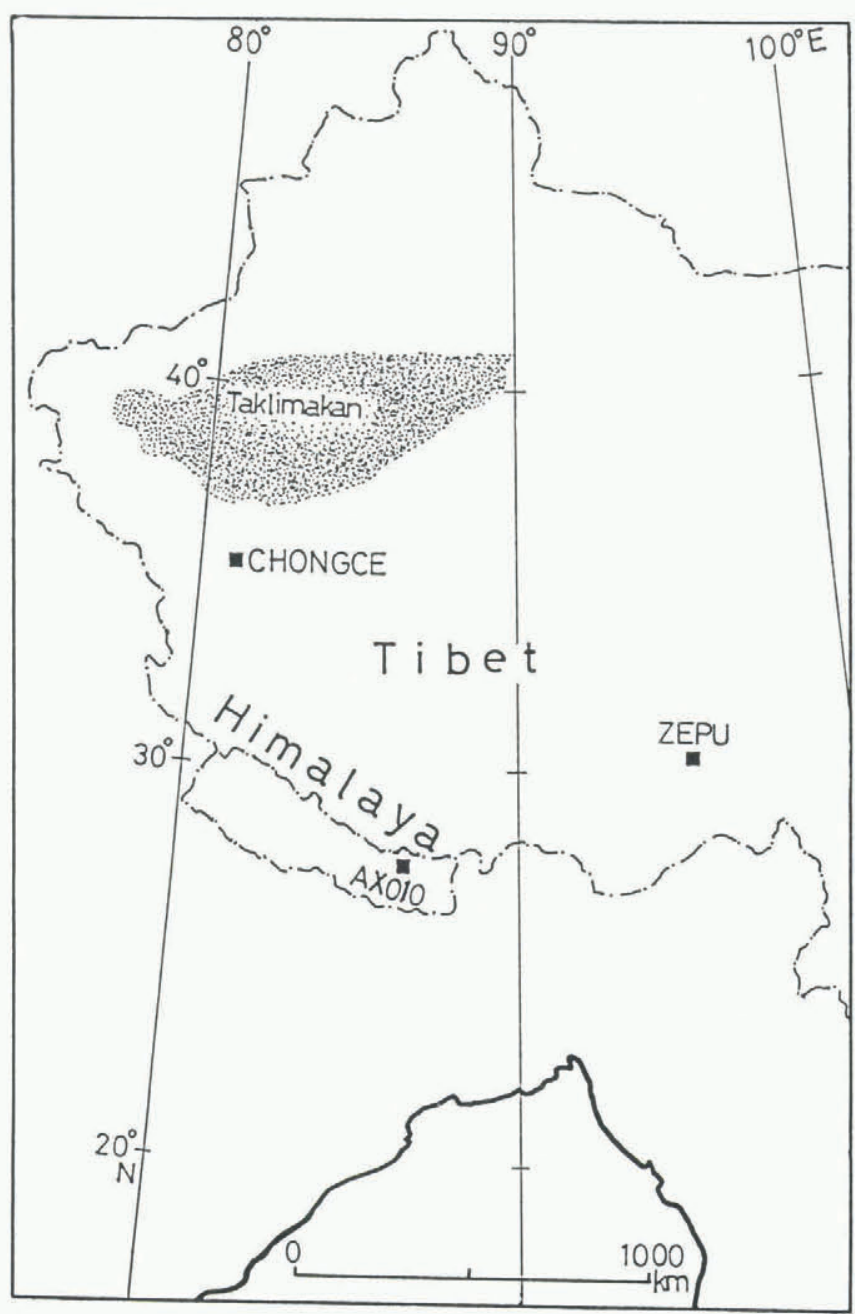

Fig. 1. Locations of the three glaciers in the Nepal Himalaya and Tibetan Plateau. 
Nyainqentanglha mountains, southeast Tibet (Zepu Glacier: $66 \mathrm{~km}^{2}$, of maritime type) and a medium-sized ice cap in west Kunlun mountains, northwest Tibet (a part of Chongce Ice Cap: $9.3 \mathrm{~km}^{2}$, of continental type). Locations of the three glaciers are shown in Figure 1.

\section{GENERAL ASSUMPTIONS FOR ESTIMATIONS OF CHANGES IN MASS BALANCE}

Estimations of changes in mass balance were made under the following simplified assumptions:

1. A rise in air temperature does not affect the amount of precipitation and other climatic factors; i.e. these factors do not change with increased temperature.

2. A rise in air temperature changes accumulation and ablation at a specific point to present those at a lower altitude in a rate of $0.6^{\circ} \mathrm{C} 100 \mathrm{~m}^{-1}$.

The first assumption is incorrect. A change in the average temperature may be associated with changes of cloudiness, precipitation and radiation. However, quantitative relations describing the effect of global warming on radiation and latent heat as well as sensible heat flux have not been obtained yet for Asian high-mountain areas. Consequently, an attempt is made in this study to derive a preliminary empirical relationship of temperature alone to glacier mass balance.

Kadota and Ageta (in press) studied the relations between the variations of Glacier AX010, air temperature and precipitation during the period from 1978 to 1989 , and concluded that the variation of the summeraccumulation type glacier was mainly controlled by the summer air temperature. Hence, in the present estimation, the amount of total precipitation in each period of the year is assumed not to change from year to year. Further, the amounts of summer precipitation, which is most of the annual precipitation in Nepal and Tibet, were found to be not so dependent on altitude on Glacier AX010 (Ageta and others, 1980), Chongce Ice Cap (Ageta and others, 1989) and other glaciers in Nepal (Higuchi and others, 1982). Therefore, it is assumed that the amount of precipitation on the glaciers is independent of altitude.

The second assumption is based on the observations of the air temperature lapse rate in summer which was $0.6^{\circ} \mathrm{C} 100 \mathrm{~m}^{-1}$ on Glacier AX010 (Ageta, 1983) and Chongce Ice Cap (Ageta and others, 1989). Since the lapse rates in winter on the glaciers have not been observed, the rate in summer is used for the calculation through a year. Differences in the lapse rate in winter and summer do not affect the results, because mass balance in winter does not depend on winter temperature.

\section{GLACIER AX010 IN THE NEPAL HIMALAYA}

Glacier AX010 is $1.7 \mathrm{~km}$ long and extends from 5381 to $4952 \mathrm{~m}$ a.s.l. from west to east-southeast.

\section{Method}

For Glacier AX010, accumulation, c, ablation, $a$ and balance, $b$, in cm water at a specific point were calculated in each half-month $(\mathrm{h})$ from the following experimental formulae obtained on Glacier AX010 (Ageta, 1983). The variables $T_{\mathrm{h}}\left({ }^{\circ} \mathrm{C}\right)$ and $P_{\mathrm{h}}(\mathrm{cm})$ are the mean air temperature and total precipitation at the specific point in each half-month, respectively. These variables were evaluated from records at the glacier terminus, using the lapse rate of $0.6^{\circ} \mathrm{C} 100 \mathrm{~m}^{-1}$ and assuming no change in the amount of precipitation with altitude.

The relations are:

$$
\begin{aligned}
c_{\mathrm{h}} & =P_{\mathrm{h}}, & & T_{\mathrm{h}}<-0.6 \\
& =P_{\mathrm{h}}\left(0.85-0.24 T_{\mathrm{h}}\right), & & -0.6 \leq T_{\mathrm{h}} \leq 3.5 \\
& =0, & & T_{\mathrm{h}}>3.5 \\
a_{\mathrm{h}} & =0, & & T_{\mathrm{h}}<-3.0 \\
& =-0.15\left(T_{\mathrm{h}}+3.0\right)^{3.2}, & & -3.0 \leq T_{\mathrm{h}} \leq 2.0 \\
& =-15\left(0.9 T_{\mathrm{h}}\right), & & T_{\mathrm{h}}>2.0 \\
b_{\mathrm{h}} & =c_{\mathrm{h}}+a_{\mathrm{h}} & &
\end{aligned}
$$

In the empirical relations above, ablation is proportional to the third power of air temperature in the temperature range from -3 to $2^{\circ} \mathrm{C}$. Krenke and Khodakov (1966) obtained a general third power relation, $a_{\mathrm{s}}=0.1\left(T_{\mathrm{s}}+9.5\right)^{3}$ between total ablation for the ablation season $\left(a_{\mathrm{s}}: \mathrm{cm}\right.$ water) and the mean air temperature from June to August $\left(T_{\mathrm{s}}:{ }^{\circ} \mathrm{C}\right)$ for various glaciers in different regions. On Glacier AX010, our relation reflects the acceleration of ablation by lowering of the albedo due to increase of the ratio of rain to total precipitation as the temperature increases in this temperature range (Ageta and others, 1980).

The annual mass-balance components $\left(c_{\mathrm{a}}, a_{\mathrm{a}}, b_{\mathrm{a}}\right)$ can be obtained as the sum of the values for each half-month throughout the year. The annual precipitation on this glacier is fixed at the present average of $160 \mathrm{~cm}$. Since the whole snowfall during winter (October to May) was observed to be lost as drifting snow due to the strong westerly winds in this locality, ablation in winter is assumed to be equal to accumulation in winter (which is $\leqslant 30 \mathrm{~cm}$ ). Details of these estimations of the present state of mass balance were published by Ageta and others (1980), Ageta (1983), and Ageta and Higuchi (1984).

\section{Results}

Calculated values of annual accumulation, ablation and

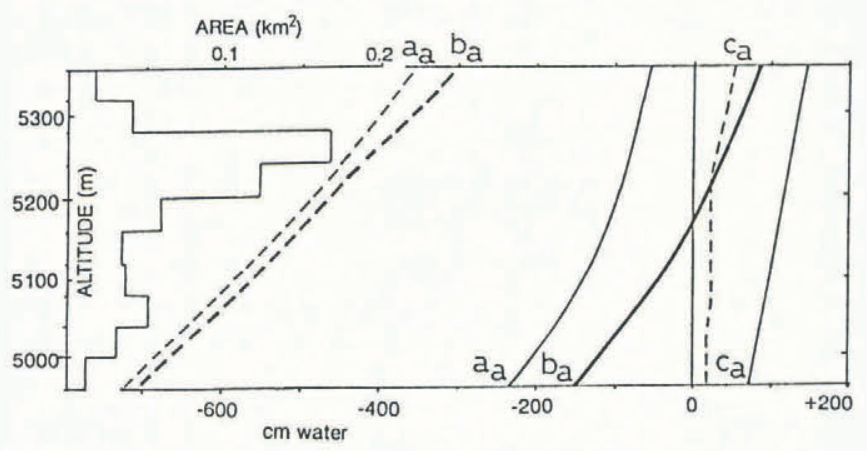

Fig. 2. Calculated annual accumulation, $c_{\mathrm{a}}$, ablation, $a_{\mathrm{a}}$, and balance, $b_{\mathrm{a}}$, of Glacier $A X 010$ in relation to altitude at an equilibrium state of mass balance for the present glacier area (solid lines) and in a case of $3^{\circ} \mathrm{C}$ warming (dashed lines). 
balance of Glacier AX010 in relation to altitude are shown in Figure 2 for an equilibrium state of mass balance and in a case of $3^{\circ} \mathrm{C}$ higher air temperature than that at the equilibrium state. An annual mean air temperature of $-4.3^{\circ} \mathrm{C}$ at the equilibrium line is derived from this model. The model predicts that annual balance has negative values, as much as $-300 \mathrm{~cm}$ at the highest altitude in a case of $3^{\circ} \mathrm{C}$ warming. Consequently, this glacier would not exist for many years in warmer conditions.

Figure 3 shows annual accumulation, ablation and balance against annual mean air temperature, $T_{\mathrm{a}}$, calculated on the basis of the experimental relations of Glacier AX010, but for a case of no drifting snow, namely no ablation in winter. The present highest and lowest altitudes of Glacier AX010 correspond to $T_{\mathrm{a}}$ levels of $H$ and $L$ as indicated in the figure, respectively. The figure predicts that $T_{\mathrm{a}}$ at the level $\mathrm{H}$ would become equal to $T_{\mathrm{a}}$ at the present equilibrium line $\left(b_{\mathrm{a}}=0\right)$, if $T_{\mathrm{a}}$ rises about $1.5^{\circ} \mathrm{C}$. In this case, the equilibrium line would reach the top of Glacier AX010. If such conditions were to continue for many years, this glacier would finally disappear.

\section{ZEPU GLACIER IN SOUTHEAST TIBET}

Zepu Glacier is $19 \mathrm{~km}$ long and extends from 6350 to $3420 \mathrm{~m}$ a.s.l. from west to east-southeast.

\section{Method}

Glaciological and meteorological observations on Zepu Glacier are available only for several days at the end of September 1989. Therefore the empirical relations for Glacier AX010 are applied to the present estimation for Zepu Glacier. Glacier AX010 is the nearest glacier to Zepu Glacier where the relation between air temperature and mass balance has been obtained. Both glaciers belong to a similar climatic setting and belong to the maritime and the summer-accumulation type.

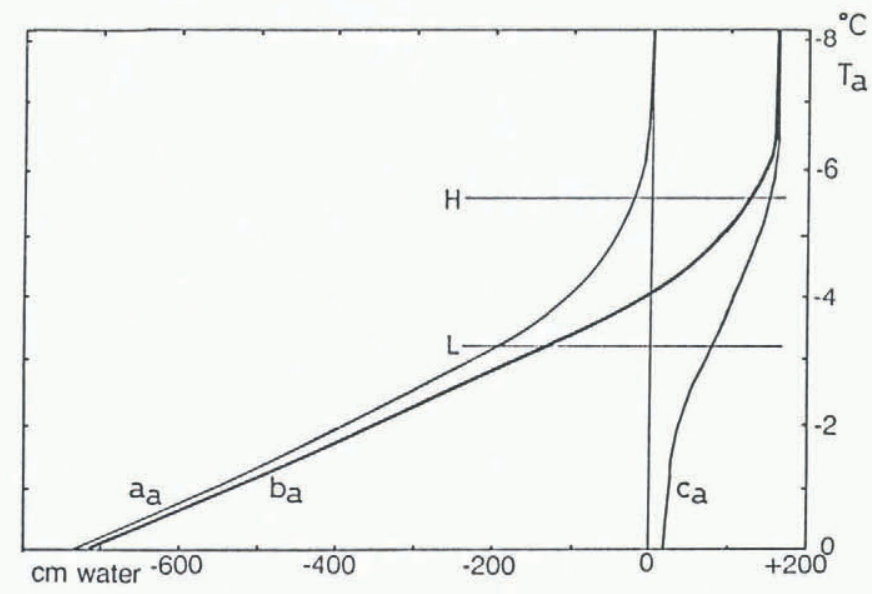

Fig. 3. Annual accumulation, $c_{\mathrm{a}}$, ablation, $a_{\mathrm{a}}$, and balance, $b_{\mathrm{a}}$, in relation to annual mean air temperature, $T_{\mathrm{a}}$, calculated on the basis of experimental data obtained from Glacier AX010. Present highest and lowest altitudes of Glacier $A X 010$ correspond to $T_{\mathrm{a}}$ levels of $H$ and $L$ in the figure.
Air temperature and precipitation on Zepu Glacier were estimated for each half-month from the averages for 1954 to 1975 at Bomi, the nearest meteorological station to the glacier $(2750 \mathrm{~m}$ a.s.l., $60 \mathrm{~km}$ southeast from the terminus). The average annual ablation of Zepu Glacier was calculated to be $264 \mathrm{~cm}$ for the whole area of the glacier, using the temperature-lapse rate of $0.6^{\circ} \mathrm{C}$ per $100 \mathrm{~m}$. For a steady-state mass balance this would equal the annual average accumulation. Such accumulation is obtained from the empirical relation, if annual precipitation is $416 \mathrm{~cm}$, assuming precipitation on the glacier increases from that at Bomi in a constant rate through a year. Further, accumulation in winter is assumed not to be lost as drifting snow. This can be justified because of the topography of the glacier in a deep valley surrounded by high ridges.

By application of the formulae derived from Glacier AX010 to the estimation for Zepu Glacier, reasonable results for the equilibrium line altitude, the activity index and the glacier flow were obtained for this glacier; this will be published elsewhere (Ageta and Furukawa, in preparation).

The lower part, about $10 \mathrm{~km}$ long, of Zepu Glacier is covered with thick supraglacial debris which inhibits ablation. The thickness of debris decreases with the altitude. It can be assumed, on the basis of observations on Khumbu Glacier in Nepal (Inoue and Yoshida, 1980), that glacier ablation beneath the debris at the terminus is zero and it increases with altitude linearly up to the altitude with maximum ablation $(4200 \mathrm{~m})$. The area of supraglacial debris cover is not large relative to the total glacier area, because the lower part of the glacier is narrow. Therefore, the above assumption of the ablation is considered not to cause much error in the estimated effect of warming on the whole area of the glacier. Details of the estimation of mass balance of Zepu Glacier at present will be published elsewhere (Ageta and Furukawa, in preparation).

\section{Results}

Calculated values of the annual accumulation, ablation and balance of Zepu Glacier in relation to the altitude are shown in Figure 4 for an equilibrium state of mass balance and in a case of $3^{\circ} \mathrm{C}$ higher air temperature than that of the equilibrium state. The annual mean air temperature at the equilibrium line for this state is derived from this model to be $-4.2^{\circ} \mathrm{C}$. The model predicts that the equilibrium line would rise $500 \mathrm{~m}$ above this equilibrium line altitude $(4860 \mathrm{~m})$ in a case of $3^{\circ} \mathrm{C}$ warming.

The equilibrium state for the whole glacier under the condition of $3^{\circ} \mathrm{C}$ warming would be obtained when the glacier terminus has retreated about $1700 \mathrm{~m}$ above the present terminus, assuming that the altitudinal distribution of the glacier area in the upper part does not change. This extent of terminus retreat depends on the altitudinal distribution of the glacier area in the lower part. Zepu Glacier is classified as a compound-basin glacier at present. However, if such warm conditions were to continue, the glacier would be transformed into several glaciers with simple basins due to retreat of the terminus, 


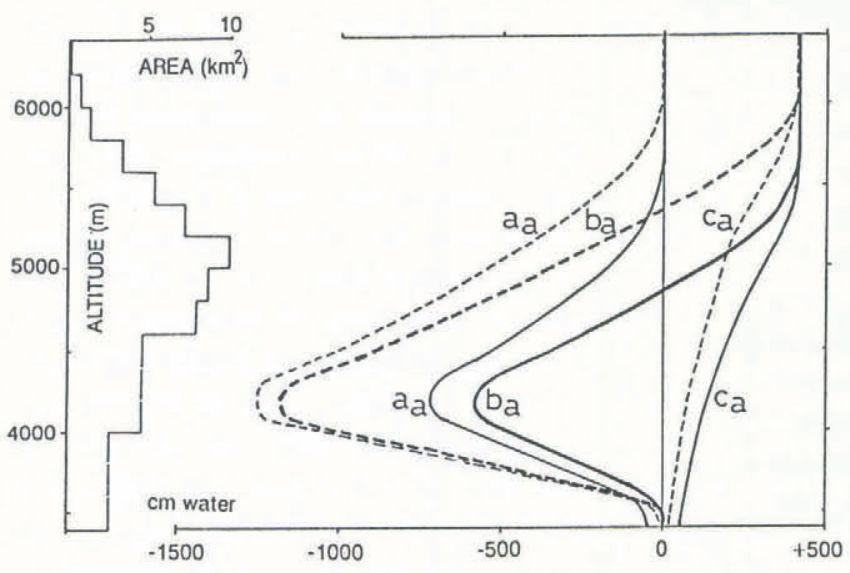

Fig. 4. Calculated annual accumulation, $c_{\mathrm{a}}$, ablation, $a_{\mathrm{a}}$, and balance, $b_{\mathrm{a}}$, of Zepu Glacier in relation to altitude at an equilibrium state of mass balance for the present glacier area (solid lines) and in a case of $3^{\circ} \mathrm{C}$ warming (dashed lines). Supraglacial debris inhibits ablation in the lower part of the glacier below $4300 \mathrm{~m}$. and fossil ice masses covered with thick supraglacial debris would remain downstream.

\section{CHONGGE ICE GAP IN NORTHWEST TIBET}

\section{Specific comments}

Chongce Ice Cap has two main peaks, the altitudes of which are 6530 and $6370 \mathrm{~m}$. The latter has a fan-shaped ice drainage with a gentle slope (Fig. 5). For the present study, the drainage is divided along ice flowlines into subdrainage areas as shown in Figure 5. The mass balance is considered to be different between slopes of different directions. We estimated the mass balance of the south slope where the observations were made. The maximum length and the lowest altitude of the present study area are $5.2 \mathrm{~km}$ and $5730 \mathrm{~m}$, respectively.

During the two years from the end of July 1985 to July

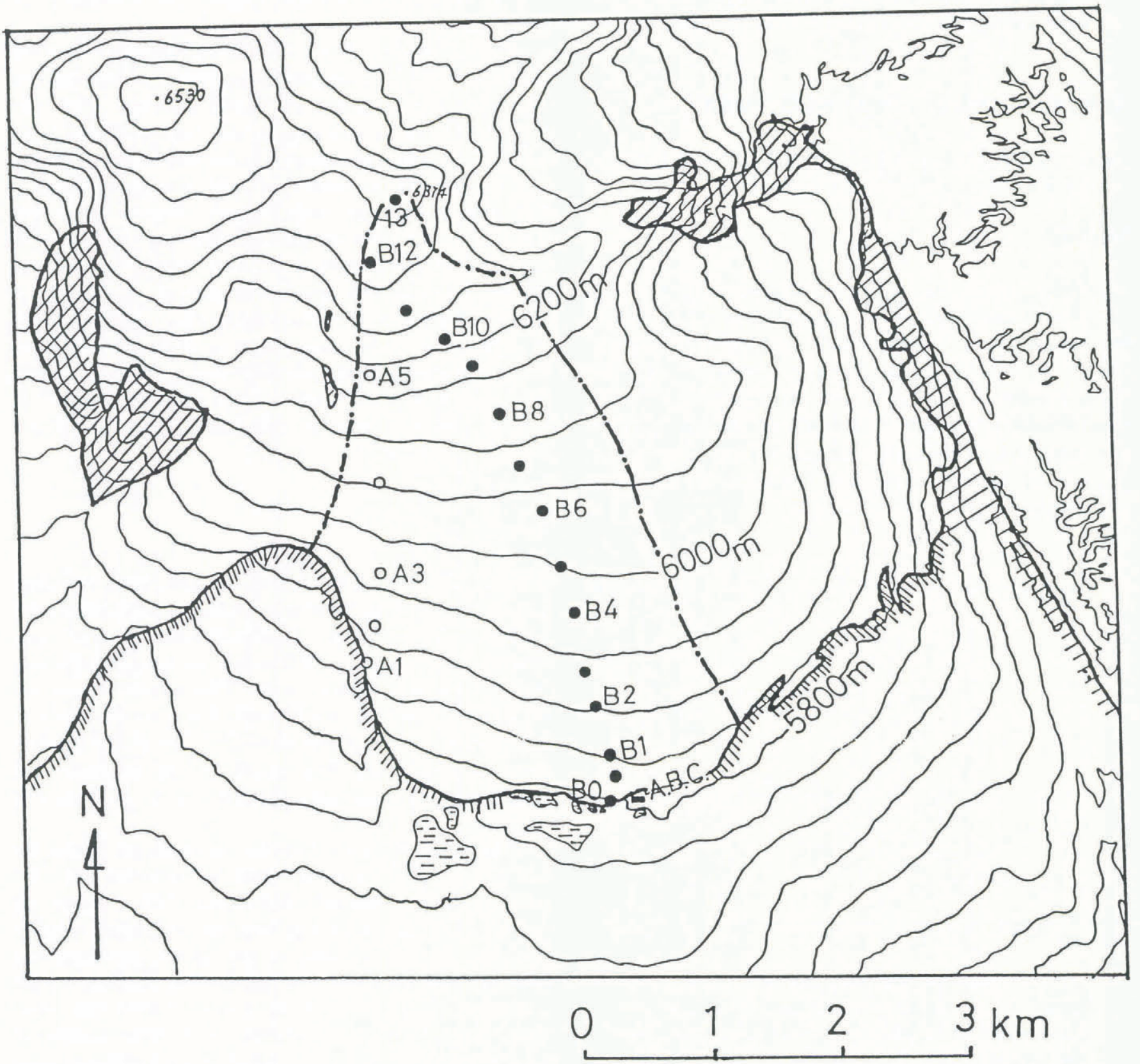

Fig. 5. Chongce Ice Cap in west Kunlun mountains, northwest Tibet. The studied sub-drainage is delineated with dashdotted lines. 
1987, mass balance was measured along the line $\mathrm{A}$ in Figure 5. The altitudinal profile of mass balance during this period showed a parabolic decrease with lowering of altitude (Ageta and others, 1989). Since all summer precipitation falls as snow on this ice cap at present, accumulation does not decrease on the lower part. Consequently, such altitudinal variation of mass balance is caused by increased ablation due to the lower albedo of dirty snow and bare ice at the lower part. Radiation is the main heat source for ablation of the continental glaciers.

For Chongce Ice Cap, an empiricial relation between annual mean air temperature and annual balance was obtained as follows.

\section{Method}

The relation between annual mass balance and altitudes of the ice cap is approximated by a power function where the altitudinal increase of annual balance is asymptotic to about $20 \mathrm{~cm}$ around the top of the ice cap. Then, the following approximation gives the annual balance, $b_{\mathrm{a}}$, in $\mathrm{cm}$, at each altitude

$$
b_{\mathrm{a}}=-0.19 \Delta T_{\mathrm{a} 0}^{3.9}+20,
$$

where $\Delta T_{\mathrm{a} 0}\left({ }^{\circ} \mathrm{C}\right)$ is the difference of annual mean air temperature from that at the altitude of $6500 \mathrm{~m}\left(-14.7^{\circ} \mathrm{C}\right)$ where $b_{\mathrm{a}}=20 \mathrm{~cm}$ for an equilibrium state of mass balance for the part of the ice cap being studied; this variable was

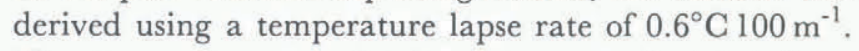
The temperature on the ice cap was calculated from automatic meteorological records throughout one year (from August 1987 to July 1988) near the ice cap at an altitude of $5260 \mathrm{~m}$ (Ohata and others, 1990) using the same lapse rate. From this equation, the annual mean air temperature at the present equilibrium line $\left(b_{\mathrm{a}}=0\right)$ is calculated as to be $-11.4^{\circ} \mathrm{C}\left(\Delta T_{\mathrm{a} 0}=3.3^{\circ} \mathrm{C}\right)$.

\section{Results}

Figure 6 shows the altitudinal profiles of annual mass balance at the equilibrium state of mass balance for the

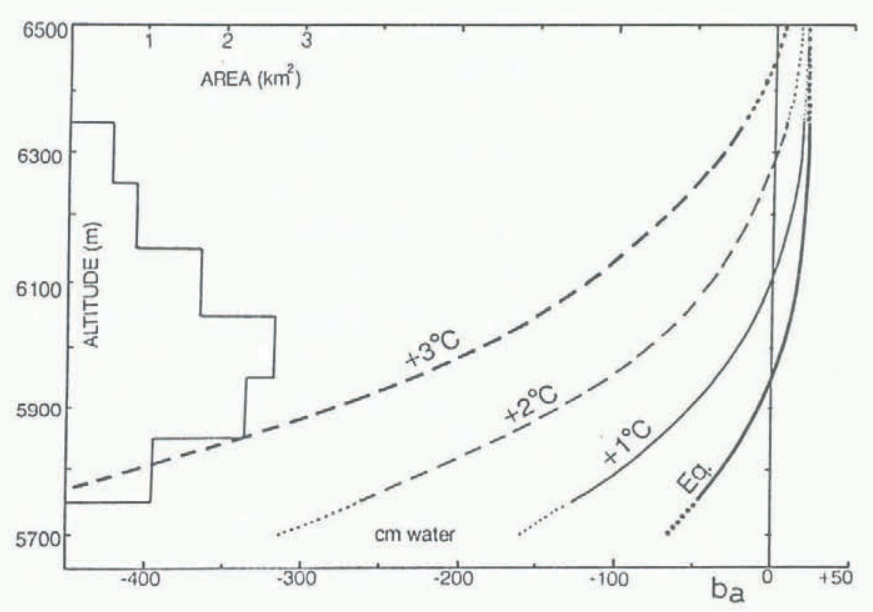

Fig. 6. Altitudinal profiles of calculated annual mass balance of Chongce Ice Cap at an equilibrium state for the whole present study area and in the cases of up to $3^{\circ} \mathrm{C}$ warming.

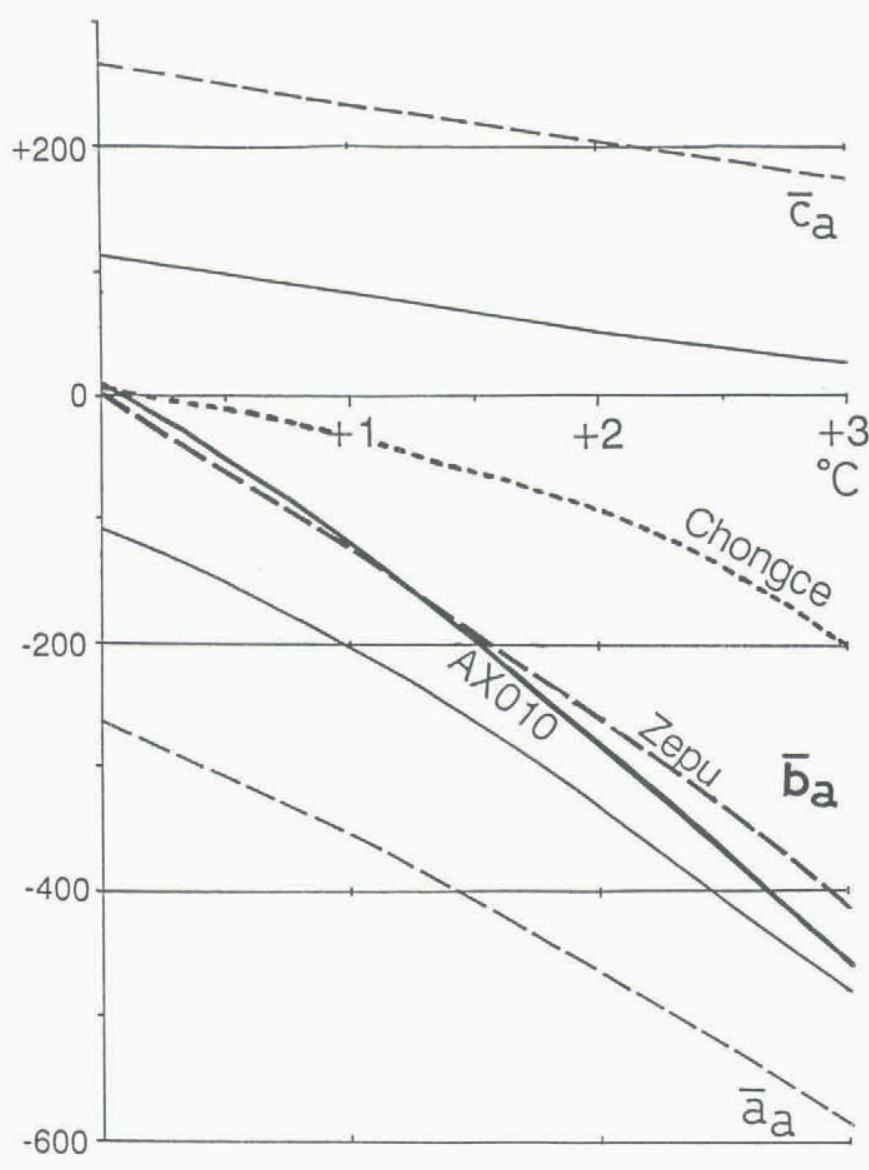

$\mathrm{cm}$ water

Fig. 7. Estimated relations between area-averaged values of annual accumulation, $\bar{c}_{\mathrm{a}}$, ablation, $\bar{a}_{\mathrm{a}}$, and balance, $\bar{b}_{\mathrm{a}}$ : thick lines, for the whole present area of each glacier, and air temperature rising above that given equilibrium state of mass balance for each glacier. Glacier AX010: solid lines, Zepu Glacier: long-dashed lines, Chongce Ice Cap: shortdashed line.

present study area and for cases with up to $3^{\circ} \mathrm{C}$ higher annual mean air temperature. The model predicts that the equilibrium line would rise to the top of the studied area if the air temperature was $2.5^{\circ} \mathrm{C}$ higher than that of the equilibrium state. For $3^{\circ} \mathrm{C}$ warming, the equilibrium line would rise to the altitude around $6450 \mathrm{~m}$. If such warmer conditions were to continue for many years, only a small ice cap would finally remain at the highest point.

\section{DISCUSSION}

Predicted results for the three glaciers are summarized in Figure 7 as relations between area-averaged values of annual accumulation, ablation and balance for the entire present area of each glacier and for air temperature rising above the equilibrium state of mass balance for each glacier. There is a major difference in the predicted annual mass exchange between Glacier AX010 and Zepu Glacier; however, both annual accumulation and ablation would decrease due to warming. Hence, a major decrease of the annual mass balance would be seen on both small and large (sub-)maritime glaciers. 
On the other hand, the predicted change of annual balance of Chongce Ice Cap due to warming is less than half in comparison with the above two glaciers. This result is mainly attributed to the difference between the (sub-)maritime and continental glaciers in the increase of the rain portion of total precipitation due to warming.

The mean annual precipitation on this continental ice cap, which corresponds to average annual accumulation for the whole area, was estimated to be around $30 \mathrm{~cm}$ by Ohata and others (1989) and Zhang and others (1989). Although accumulation of snow may decrease under warmer conditions due to rain at the lower part in the warmest months, change of annual balance of the ice cap, as shown in Figure 7, is considered to be controlled mainly by a change of annual ablation.

At a warming of $3^{\circ} \mathrm{C}$, the model predicts that Glacier AX010 would have a negative annual balance which corresponds to about $5 \mathrm{~m}$ in average ice thickness (Fig. 7). The average thickness of the glacier is about $50 \mathrm{~m}$ at present (Ikegami and Ageta, 1991), and it would disappear within a few decades under warmer conditions.

\section{CONCLUDING REMARKS}

The shrinkages of three glaciers of the summer-accumulation type were estimated and compared using a model based on simplified experimental relations between air temperature and mass balance. The model predicted that the shrinkages of both small and large (sub-)maritime glaciers were more sensitive to a rise of air temperature than the continental ice cap. Further, the small glacier would disappear in a few decades under the continued conditions of air temperature a few degrees warmer than that of the present state.

The present model, which predicts that ablation is proportional to the third power of the air temperature, up to $2^{\circ} \mathrm{C}$, and linearly above $2^{\circ} \mathrm{C}$, has many shortcomings. The model does not describe the components of the energy balance and does not separate the effects of temperature increase from that of other climatic variables such as cloudiness and precipitation. Hence, the parametrization of our model may not be suitable for modelling the effects of climatic changes as large as $3 \mathrm{~K}$.

The evaluations of changing effects of supraglacial debris and surface albedo on ablation require further study. However, the present method gives a preliminary assessment, from the limited data available, of the effects of air temperature change for maritime and continental glaciers of the summer-accumulation type. The model may overestimate the effect of warming. Monitoring of glacier variations and air temperature at high altitudes, which may be different from that observed at stations at low altitudes, as well as detailed energy-balance studies are required for improved predictions of glacier variations due to climatic warming. In particular, warming in summer is important for the summer-accumulation type glaciers in Asian high-mountain areas.

\section{ACKNOWLEDGEMENTS}

We thank Dr H. Björnsson (Science Institute, University of Iceland) and anonymous referees for many helpful comments.

\section{REFERENCES}

Ageta, Y. 1983. Characteristics of mass balance of the summer-accumulation type glacier in the Nepal Himalaya. Seppyo, 45(2), 81-105. [In Japanese with English abstract.]

Ageta, Y. and K. Higuchi. 1984. Estimation of mass balance components of a summer-accumulation type glacier in the Nepal Himalaya. Geogr. Ann., 66A(3), 249-255.

Ageta, Y., T. Ohata, Y. Tanaka, K. Ikegami and K. Higuchi. 1980. Mass balance of Glacier AX010 in Shorong Himal, east Nepal during the summer monsoon season. Seppyo, 41, Special Issue, 34-41.

Ageta, Y., Zhang Wenjing and M. Nakawo. 1989. Mass balance studies on Chongce Ice Cap in the west Kunlun mountains. Bull. Glacier Res. 7, 37-43.

Higuchi, K., Y. Ageta, T. Yasunari and J. Inoue. 1982. Characteristics of precipitation during the monsoon season in high-mountain areas of the Nepal Himalaya. International Association of Hydrological Sciences Publication 138 (Symposium at Exeter 1982 - Hydrological Aspects of Alpine and High-Mountain Areas), 21-30.

Ikegami, K. and Y. Ageta. 1991. Ice flow of Glacier AX010 in the Nepal Himalaya. Bull. Glacier Res. 9, 1722.

Inoue, J. and M. Yoshida. 1980. Ablation and heat exchange over the Khumbu Glacier. Seppyo, 41, Special Issue, 26-33.

Kadota, T. and Y. Ageta. In press. On the relation between climate and retreat of Glacier AX010 in the Nepal Himalaya from 1978 to 1989. Bull. Glacier Res.

Krenke, A.N. and V.G. Khodakov. 1966. O svyazi poverkhnostnogo tayaniya lednikov $\mathrm{s}$ temperaturoy vozdukha [About relation of surface melting with air temperature]. Materialy Glyatsiologicheskikh Issledovaniy. Khronika. Obsuzhdeniya 12, 153-164.

Ohata, T., S. Takahashi and Kang Xiangchen. 1989. Meteorological conditions of the west Kunlun mountains in the summer of 1987. Bull. Glacier Res. 7, 67-76.

Ohata, T., Kang Xiangchen and S. Takahashi. 1990. Full year surface meteorological data at northwestern Tibetan Plateau using an automatic observation system. Bull. Glacier Res. 8, 73-85.

Zhang Wenjing, An Ruizhen, Yang Huian and Jiao Keqing. 1989. Conditions of glacier development and some glacial features in the west Kunlun mountains. Bull. Glacier Res., 7, 49-58.

The accuracy of references in the test and in this list is the responsibility of the author $/ s$, to whom queries should be addressed. 